\title{
PENGARUH VARIASI KONSENTRASI METANOL DAN LAMA INDUKSI TERHADAP EKSPRESI PROINSULIN OLEH Pichia pastoris SECARA INTRASELULER
}

\section{The Effects of Variation in Methanol Concentration and Induction Time on Intracellular Proinsulin Expression by Pichia pastoris}

\author{
Efrida Martius ${ }^{1, *}$, Andree Triyadi ${ }^{2}$, Dewi Yustika ${ }^{2}$, Anis Herliyanti Mahsunah ${ }^{1}$ \\ ${ }^{1}$ Balai Bioteknologi, BPPT, Gedung 630 Kawasan Puspiptek, Setu, Tangerang Selatan, Banten 15314 \\ 2Universitas Surya, Grand Serpong Mall Lt. 1 unit F8 \& F9, JI. M.H. Thamrin Km 2.7, Panunggangan \\ Utara, Pinang, Kota Tangerang, Banten 15143 \\ *Email: efrida.martius@bppt.go.id
}

\begin{abstract}
Diabetes is a metabolic disorder characterized by hyperglycemia. There were 215 million diabetic patients in 2014 and the number is expected to rise in 2040. Generally, insulin is used to treat diabetic patients. Insulin production by recombinant technology has been done, though still inefficient, by using $\mathrm{E}$. coli and S. cerevisiae expression system. Another alternative expression system is methylotrophic yeast Pichia pastoris. In this research, proinsulin has been expressed by $P$. pastoris intracellularly. $\mathrm{P}$. pastoris strains used in this research were X33, GS115, and KM71H. All recombinant strains were Mut ${ }^{S}$. Best cultivation media was $B M G Y$. Proinsulin expression was observed at $25^{\circ} \mathrm{C}$. Pichia pastoris strain that expressed proinsulin best was GS115-PI. It was supported by PCR in which the strain GS115-PI gave $504 \mathrm{bp}$-sized bands. Based on proinsulin formation time, the final methanol concentration of $0.5 \%$ in 72 hours was found to be the best treatment.
\end{abstract}

Keywords: BMGY, methanol, phenotype, Pichia pastoris, proinsulin

\begin{abstract}
ABSTRAK
Diabetes melitus merupakan kelainan yang ditandai dengan hiperglikemia. Penderita diabetes pada tahun 2014 di dunia mencapai 215 juta dan diperkirakan akan meningkat pada tahun 2040. Umumnya penderita diabetes diberi pengobatan insulin sehingga menunjukkan akan ada peningkatan kebutuhan insulin. Produksi insulin dengan teknologi DNA rekombinan telah dilakukan dengan menggunakan sistem ekspresi $E$. coli dan $S$. cerevisiae namun masih belum efisien. Sistem alternatif lain adalah ragi metilotropik Pichia pastoris. Dalam penelitian ini dilakukan ekspresi proinsulin dari $P$. pastoris secara intraseluler. Galur $P$. pastoris yang digunakan dalam penelitian ini adalah X33, GS115, dan KM71H. Semua galur rekombinan adalah Muts. Media tumbuh terbaik adalah BMGY. Ekspresi proinsulin terlihat pada suhu $25^{\circ} \mathrm{C}$. Hasil PCR menunjukkan bahwa galur GS115-PI yang dapat menghasilkan pita amplikon berukuran 504 bp. Hasil PCR ini dibuktikan oleh hasil seleksi galur yang menunjukkan bahwa galur GS115-PI dapat mengekspresi proinsulin dibandingkan galur lainnya. Berdasarkan kecepatan pembentukan pita protein proinsulin, variasi konsentrasi akhir metanol 0,5\% dengan lama induksi 72 jam merupakan perlakuan terbaik.
\end{abstract}

Kata Kunci: BMGY, fenotipe, metanol, Pichia pastoris, proinsulin 


\section{PENDAHULUAN}

Diabetes mellitus merupakan suatu kelainan metabolik yang ditandai dengan hiperglikemia karena tidak adanya atau rendahnya kadar insulin dalam tubuh (Baeshen et al. 2016). Diabetes mellitus umumnya dibagi menjadi dua tipe yaitu tipe I dan tipe II. Tipe I disebabkan rendahnya produksi insulin dari tubuh, sedangkan tipe II disebabkan tubuh tidak dapat menggunakan insulin yang dihasilkan (WHO 2016). Berdasarkan perkiraan International Diabetes Federation (IDF 2015), prevalensi diabetes di dunia sebesar 415 juta jiwa dan di Indonesia sebesar 10 juta jiwa. Indonesia sendiri berada pada posisi ke tujuh setelah China, India, Amerika Serikat, Brazil, Rusia, dan Meksiko. Berdasarkan perkiraan IDF, angka penderita diabetes akan semakin meningkat sehingga jumlah penderita diabetes mencapai 642 juta jiwa pada tahun 2040. Akibatnya posisi Indonesia diperkirakan akan naik ke posisi enam. Secara umum penderita diabetes diobati dengan insulin sehingga keperluan insulin akan semakin meningkat.

Insulin merupakan hormon sepanjang 51 asam amino yang diproduksi oleh sel $\beta$ pakreas. Hormon ini berfungsi dalam pengaturan metabolisme gula darah (Gurramkonda et al. 2010). Pada awalnya insulin diproduksi dari pankreas hewan, namun insulin yang dihasilkan dari hewan mengakibatkan komplikasi. Sehingga metode produksi diganti ke rekayasa produksi analog insulin (Quainzon dan Cheikh 2012). Umumnya prekursor insulin (proinsulin) telah diekspresikan melalui $E$. coli atau $S$. cerevisiae. Meskipun E. coli memiliki laju pertumbuhan yang sangat cepat, protein yang dihasilkan akan membentuk badan inklusi sehingga perlu dilakukan solubililasi dan pelipatan ulang (Polez et al. 2016). Prekursor insulin larut yang dihasilkan dari $S$. cerevisiae dapat disekresi ke dalam supernatan (Gurramkonda et al. 2010). Namun protein yang dihasilkan oleh $S$. cerevisiae mengalami hiperglikosilasi berlebih. Selain itu, protein terglikosilasi dari S. cerevisiae memiliki ikatan $\alpha 1,3$ glikan yang bersifat hiperantigenik. Akibatnya, protein tersebut tidak terlalu cocok untuk diaplikasikan sebagai senyawa terapeutik ke manusia (Baeshen et al. 2016).
Pichia pastoris merupakan sistem ekspresi alternatif yang menjanjikan. $P$. pastoris merupakan ragi metilotropik yang dapat menggunakan metanol sebagai sumber karbon (Shen et al. 2016). Ragi ini memiliki beberapa keuntungan seperti: dapat mencapai densitas sel yang tinggi, kultur medium yang murah, memiliki promoter AOX1 yang berkontribusi dalam kualitas serta kuantitas protein yang dihasilkan (Baeshen et al. 2014). $P$. pastoris berpotensi untuk memproduksi protein rekombinan prokariot atau eukariot yang diproses dengan benar (secara intraseluler maupun ekstraseluler) (Looser et al. 2015), serta protein yang dihasilkan oleh $P$. pastoris tidak mengalami glikosilasi berlebih sehingga protein tersebut lebih mirip struktur protein eukariot tinggi (Baeshen et al. 2016). Pada umumnya terdapat tiga galur $P$. pastoris yang digunakan dalam produksi protein rekombinan yaitu X33, GS115, dan KM71H (Ahmad et al. 2014; Sturmberger et al. 2016; Safder et al. 2018).

$P$. pastoris telah digunakan untuk mengekspresi beragam protein seperti insulin, gen lysozime, dan pleucidin cDNA (Baeshen et al. 2016; Samalla 2015). Penelitian tentang ekspresi proinsulin secara ekstraseluler dari $P$. pastoris juga telah dilakukan dengan hasil yang memuaskan. Hasil penelitian dari Baeshen et al. (2016) menunjukkan ekspresi proinsulin secara ekstraseluler sebanyak $5 \mathrm{mg} / \mathrm{L}$ dengan volume kultivasi sebanyak $25 \mathrm{~mL}$. Ekspresi protein secara intraseluler mempunyai keunggulan berupa hasil produksi protein lebih tinggi dibanding ekspresi secara ekstraseluler karena protein akan terhindar dari hidrolisis oleh produk metabolik sel seperti enzim proteolitik (Yin et al. 2012). Metanol sebagai sumber karbon yang digunakan untuk menginduksi ekspresi proinsulin dari P. pastoris (Vanz et al. 2014). Gurramkonda et al. (2010) menggunakan 6 $\mathrm{g} / \mathrm{L}$ metanol untuk memproduksi proinsulin secara ekstraseluler namun terjadi penurunan produksi proinsulin dan kematian sel. Maka dari itu Gurramkonda et al. (2010) menurunkan konsentrasi metanol menjadi 2 $\mathrm{g} / \mathrm{L}$ dan tidak terjadi kematian sel. Hal ini menunjukkan bahwa konsentrasi metanol yang digunakan berperan dalam viabilitas dan kemampuan ekspresi $P$. pastoris. 
Berdasarkan kemampuan $P$. pastoris yang telah dijelaskan di atas, maka tujuan penelitian ini adalah untuk mengkaji kemampuan ekspresi proinsulin oleh beberapa galur $P$. pastoris serta mengkaji pengaruh variasi konsentrasi dan lama induksi terhadap ekspresi proinsulin secara intraseluler.

\section{BAHAN DAN METODE}

\section{Waktu dan tempat penelitian}

Penelitian ini dilakukan di Laboratorium Balai Bioteknologi, Badan Pengkajian dan Penerapan Teknologi (BPPT) Gedung 630, Kawasan Puspiptek, Tangerang Selatan, Banten. Waktu penelitian dimulai dari September 2017- Agustus 2018.

\section{Kloning plasmid}

Plasmid pPICZA-PI ditransformasi ke dalam sel kompeten $E$. coli TOP10 mengikuti metode dari Sambrook dan Russel (2001). Sel E. coli rekombinan ditumbuhkan ke dalam media Luria Broth (LB) rendah garam padat ( $1 \%$ tripton, $0,5 \%$ yeast extract, $0,5 \% \mathrm{NaCl}$, dan $2 \%$ agar) dengan suplementasi $25 \mu \mathrm{g} / \mathrm{mL}$ Zeocin $^{\text {TM }}$ pada suhu $37^{\circ} \mathrm{C}, 16-18$ jam. Koloni tunggal yang tumbuh kemudian diregenerasi untuk keperluan isolasi plasmid dalam media LB rendah garam cair dengan suplementasi Zeocin $^{\text {TM }}$ pada suhu $37^{\circ} \mathrm{C}, 160 \mathrm{rpm}, 16-18$ jam. Isolasi plasmid dilakukan dengan kit high-speed plasmid mini dari Geneaid (Taipei). Hasil isolasi kemudian dilinearisasi dengan Sacl sesuai prosedur Thermo Fisher (Massachussets). Hasil isolasi dan linearisasi dianalisis dengan elektroforesis agarosa.

\section{Transformasi $\boldsymbol{P}$. pastoris}

Proses pembuatan sel kompeten dan transformasi $P$. pastoris menggunakan kit EasyComp $^{\mathrm{TM}}$ (Invitrogen, USA). Sel kompeten $P$. pastoris ditransformasi dengan plasmid pPICZA dan pPICZA-PI. Sel rekombinan ditumbuhkan dalam media padat YPD (1\% yeast extract, 2\% pepton, 2\% dekstrosa, dan $2 \%$ agar) dengan suplementasi $100 \mu \mathrm{g} / \mathrm{mL}$ Zeocin $^{\mathrm{TM}}$ pada suhu $28^{\circ} \mathrm{C}$ selama 4 hari. Koloni tunggal yang tumbuh diregenerasi untuk keperluan pembuatan stok gliserol. Stok gliserol disimpan dalam $-80^{\circ} \mathrm{C}$.

\section{Seleksi klon}

Proses seleksi klon dilakukan dengan menumbuhkan koloni $P$. pastoris hasil transformasi dalam media buffered complex medium containing glycerol (BMGY) (1\% yeast extract, $2 \%$ peptone, $100 \mathrm{mM}$ bufer kalium fosfat $\mathrm{pH} 6,0,1,34 \%$ YNB, $4 \times 10^{-5} \%$ biotin, dan $1 \%$ gliserol) pada suhu $30^{\circ} \mathrm{C}, 250$ rpm selama 1 hari. Kultur disentrifugasi pada hari selanjutnya dan pelet diresuspensi dalam buffered minimal medium containing methanol and/or histidine $(\mathrm{BMM}(\mathrm{H}))(100 \mathrm{mM}$ bufer kalium fosfat $\mathrm{pH} 6,0,1,34 \%$ YNB, 4 $\times 10^{-5} \%$ biotin, $0,5 \%$ metanol, dan $0,004 \%$ histidine) pada suhu $25^{\circ} \mathrm{C}, 250 \mathrm{rpm}$. Sebanyak $1 \mathrm{~mL}$ sampel diambil dan induksi metanol sebanyak $0,5 \%$ dilakukan setiap 24 jam. Ekstraksi protein intraseluler $P$. pastoris rekombinan dilakukan berdasarkan prosedur dari Haar (2007). Analisa protein intraseluler dilakukan dengan Tricine SDS-PAGE.

\section{Analisa pita protein dengan SDS-PAGE}

Analisa SDS-PAGE dilakukan berdasarkan metode dari Schägger (2006). Alat SDS-PAGE yang digunakan yaitu produk ATTO (AE6450). Elektroforesis dilakukan dalam dua bufer yaitu bufer katoda (Trisin 1 $\mathrm{M}$, Tris $1 \mathrm{M}$, SDS 1\%) di bagian dalam tangki dan bufer anoda (Tris $1 \mathrm{M}$ ). Gel kemudian divisualisasi dengan Coomassie Brilliant Blue (CBB) R-250. Pada awalnya gel direndam dalam larutan fiksasi (amonium asetat $0,1 \mathrm{M}$, metanol $50 \%$, asam asetat $10 \%$ ), kemudian dalam larutan staining (CBB R-250 0,1\%, metanol $40 \%$, asam asetat $10 \%$ ) selama 30 menit dan dalam larutan destaining (metanol $40 \%$, asam asetat $10 \%$ ) hingga terlihat pita protein dan gel menjadi bening.

Pewarnaan perak dilakukan jika pita protein tidak terlihat setelah pewarnaan CBB $\mathrm{R}-250$. Prosedur pewarnaan perak mengikuti prosedur Chevallet et al. (2006). Gel yang telah diwarnai dengan CBB R-250 direndam ke dalam larutan $50 \mathrm{mM}$ amonium hidrogen karbonat kemudian ke dalam larutan fiksasi $(30 \%(\mathrm{v} / \mathrm{v})$ etanol, $10 \%(\mathrm{v} / \mathrm{v})$ asam asetat). Selanjutnya gel dibilas dalam larutan $30 \%$ $(\mathrm{v} / \mathrm{v})$ etanol dan dilanjutkan dengan pembilasan gel dalam air ultrapure. Kemudian gel disensitasi dalam $0,8 \mathrm{mM}$ $\mathrm{Na}_{2} \mathrm{~S}_{2} \mathrm{O}_{3}$ dan dilanjutkan dengan inkubasi dalam larutan $12 \mathrm{mM} \mathrm{AgNO}_{3}$. Setelah itu gel diinkubasi dalam larutan developer (3\% (w/v) $\mathrm{K}_{2} \mathrm{CO}_{3}+6,25 \mu \mathrm{L} 10 \%(\mathrm{w} / \mathrm{v}) \mathrm{Na}_{2} \mathrm{~S}_{2} \mathrm{O}_{3}+14 \mu \mathrm{L}$ 
formalin 37\%). Pewarnaan gel dilakukan hingga cukup. Selanjutnya gel direndam dalam larutan stop (4\% (w/v) Tris $+2 \%(\mathrm{v} / \mathrm{v})$ asam asetat). Pada tahap akhir, gel dibilas dalam air ultrapure.

\section{Konfirmasi hasil integrasi gen proinsulin}

Tiga koloni terpilih hasil seleksi ditumbuhkan dalam media cair YPD + Zeocin pada suhu $30^{\circ} \mathrm{C}, 160 \mathrm{rpm}$ selama 20 jam. Selanjutnya dilakukan isolasi genom mengikuti prosedur Bust n' Grab dari Harju et al. (2004). Konsentrasi genom diukur dengan menggunakan spektrofotometer Nanodrop ${ }^{\mathrm{TM}}$ (Thermoscientific).

Tahap PCR dilakukan dengan menggunakan thermal cycler (TaKaRa). Konsentrasi genom hasil isolasi dilakukan pengenceran sebanyak 50x. Komposisi reagen yang ditambahkan per satu sampel adalah nuclease free water $(11,4 \mu \mathrm{L}), 10 \times$ bufer $(2 \mu \mathrm{L}), 25 \mathrm{mM} \mathrm{MgSO}_{4}(1,5 \mu \mathrm{L})$, dNTP (2 $\mu \mathrm{L})$, primer $\mathrm{F}(0,8 \mu \mathrm{L})$, primer $\mathrm{R}(0,8 \mu \mathrm{L})$, DNA polimerase $(0,5 \mu \mathrm{L})$, dan DNA template (1 $\mu \mathrm{L})$. Hasil PCR dianalisis dengan elektroforesis agarosa kemudian pita amplikon divisualisasi dengan UV Transluminator.

\section{Uji fenotipe}

Uji fenotipe dilakukan dengan menumbuhkan $P$. pastoris rekombinan hasil seleksi koloni dalam media padat minimal medium containing methanol and/or histidine

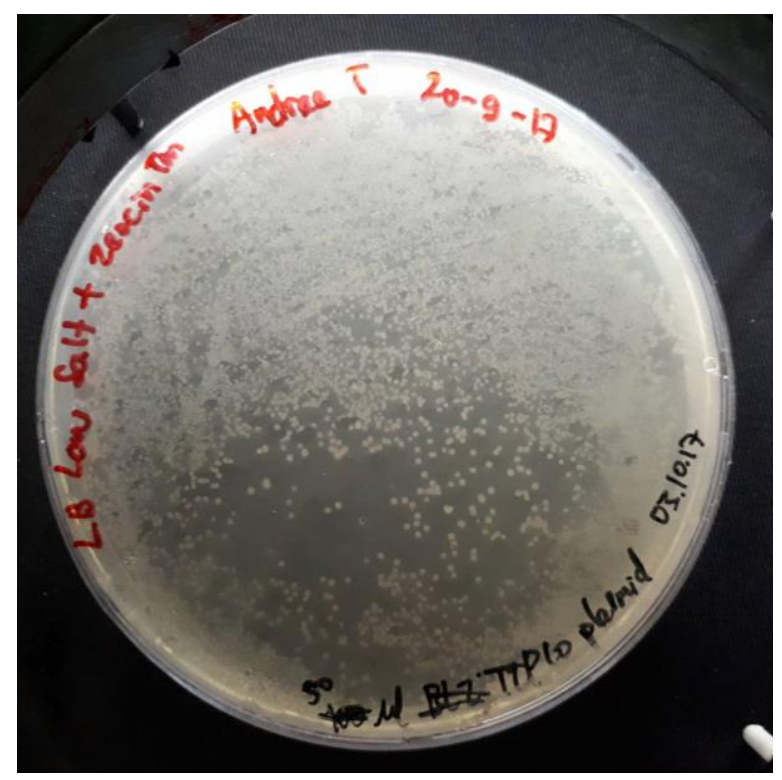

Gambar 1. Hasil transformasi E. coli TOP10 dengan plasmid pPICZA-PI
$(\mathrm{MM}(\mathrm{H}))\left(1,34 \%\right.$ YNB, $4 \times 10^{-5}$ biotin, $0,5 \%$ metanol, $0,004 \%$ histidin, $2 \%$ agar) dan minimal medium containing glycerol and/or histidine $(\mathrm{MD}(\mathrm{H}))\left(1,34 \%\right.$ YNB, $4 \times 10^{-5}$ biotin, $1 \%$ gliserol, $0,004 \%$ histidin, $2 \%$ agar). $P$. pastoris rekombinan ditumbuhkan dalam media $\mathrm{MM}(\mathrm{H})$ terlebih dahulu kemudian dalam media $\mathrm{MD}(\mathrm{H})$ pada suhu $30^{\circ} \mathrm{C}$ selama 48 jam. Berdasarkan kecepatan penggunaan metanol, fenotipe dari $P$. pastoris dibagi menjadi $\mathrm{Mut}^{+}$(penggunaan metanol normal) dan Mut $^{S}$ (penggunaan metanol lambat). Kontrol $\mathrm{Mut}^{+}$yang ditumbuhkan dalam masing-masing media adalah GS115/pPICZ/lacz dan kontrol Mut $^{\text {s }}$ yang ditumbuhkan adalah GS115 Albumin. Pengamatan kecepatan pertumbuhan sampel dilakukan setiap 24 jam.

\section{Seleksi galur}

Tiga koloni terpilih hasil seleksi ditumbuhkan dalam media BMGY pada suhu $30^{\circ} \mathrm{C}, 250 \mathrm{rpm}$ selama 1 hari. Kultur disentrifugasi pada hari selanjutnya dan pelet dipindah ke dalam media BMM(H). Ekspresi proinsulin dilakukan pada suhu $25^{\circ} \mathrm{C}, 250$ rpm, selama 4 hari. Sebanyak $1 \mathrm{~mL}$ sampel diambil dan 0,5\% metanol ditambah setiap 24 jam. Sampel protein dianalisis dengan Tricine SDS-PAGE.

\section{Optimasi ekspresi proinsulin}

GS115-PI ditumbuhkan dalam media BMGY pada suhu $30^{\circ} \mathrm{C}, 250 \mathrm{rpm}, 1$ hari. Kultur disentrifugasi pada hari selanjutnya dan pelet diresuspensi dalam media BMM $(H)$. Ekspresi proinsulin dilakukan pada suhu 25으, 250 rpm, selama 6 hari. Sebanyak $1 \mathrm{~mL}$ sampel diambil setiap 1 hari. Variasi konsentrasi akhir metanol sebesar 0,5, 1, 1,5 dan $2 \%$ ditambahkan ke dalam kultur setiap 1 hari. Analisa protein dilakukan menggunakan Tricine SDS-PAGE.

\section{HASIL DAN PEMBAHASAN}

\section{Kloning plasmid pPICZA-PI}

Proses transformasi plasmid pPICZA$\mathrm{PI}$ ke dalam $E$. coli berhasil karena $E$. coli rekombinan dapat tumbuh dalam media dengan suplementasi Zeocin. Hal ini menunjukkan bahwa $E$. coli rekombinan mengandung plasmid pPICZA-PI yang memiliki marka resistensi terhadap Zeocin sehingga $E$. coli dapat tumbuh pada media 
tersebut. Pertumbuhan E. coli rekombinan memenuhi permukaan media sehingga efisiensi transformasi tidak dapat dihitung. Hasil transformasi E. coli ditampilkan dalam Gambar 1.

Koloni tunggal yang tumbuh kemudian diregenerasi dalam media LB cair dengan suplementasi Zeocin untuk keperluan isolasi plasmid. Terdapat dua jenis $E$. coli rekombinan yang ditumbuhkan dalam media yaitu $E$. coli yang mengandung plasmid pPICZA (plasmid tanpa gen sisipan) dan $E$. coli yang mengandung plasmid pPICZA-PI (plasmid dengan gen sisipan). Proses transformasi $E$. coli dengan pPICZA telah dilakukan oleh peneliti Balai Bioteknologi (BPPT). Proses transformasi dilakukan menggunakan metode Sambrook dan Russel (2001) sesuai dengan metodologi yang telah dijelaskan sebelumnya. Plasmid pPICZA berukuran $3,3 \mathrm{~kb}$ dan ukuran sisipan gen $\mathrm{PI}$ berukuran 179 pb sehingga plasmid pPICZA$\mathrm{PI}$ akan berukuran 3,479 kb. Hal ini akan menyebabkan adanya perbedaan posisi kedua pita plasmid pada gel elektroforesis.

Isolasi plasmid berhasil yang ditunjukkan dengan adanya pita pada gel elektroforesis. Meskipun begitu, konsentrasi DNA hasil isolasi masih rendah dilihat dari hasil pengukuran konsentrasi dengan Nanodrop ${ }^{\mathrm{TM}}$ maupun dari hasil visualisasi pita DNA. Rendahnya konsentrasi hasil isolasi plasmid kemungkinan disebabkan sel bakteri tidak terlisis sempurna, nuclease-free water yang ditambahkan tidak tepat di tengah matriks kolom, atau proses elusi plasmid yang tidak sempurna. Faktor lain yang mempengaruhi hasil isolasi plasmid adalah ukuran plasmid, jumlah salinan plasmid (copy number), dan kondisi pertumbuhan bakteri (Pronobis et al. 2016). Plasmid hasil isolasi kemudian dilinearisasi. Hasil isolasi dan linearisasi plasmid ditunjukkan dalam Gambar 2. Berdasarkan hasil linearisasi, kedua jenis plasmid tersebut telah linear. Plasmid pPICZA-PI menunjukkan ukuran sebesar $\pm 3,5 \mathrm{~kb}$, sedangkan plasmid pPICZA sebesar 3,3 kb. Ukuran plasmid pPICZA-PI lebih besar dari plasmid pPICZA karena mengandung gen sisipan sehingga sesuai dengan ukuran teoritis. Plasmid yang linear ini kemudian ditransformasi ke dalam $P$. pastoris.

\section{Transformasi $\boldsymbol{P}$. pastoris}

Terdapat 3 galur $P$. pastoris yang digunakan dalam proses transformasi yaitu X33, GS115, dan KM71H. Masing-masing galur ini ditransformasi dengan plasmid pPICZA dan pPICZA-PI sehingga galur $P$. pastoris selanjutnya ditambah huruf $A$ (untuk $P$. pastoris dengan plasmid pPICZA, contoh: X33A), dan ditambah huruf $\mathrm{PI}$ (untuk $P$. pastoris dengan plasmid pPICZA-PI, contoh: X33-PI). Proses transformasi $P$. pastoris berjalan dengan baik seperti yang ditunjukkan dalam Gambar 3. Masing-masing galur $P$. pastoris rekombinan dapat tumbuh dalam media YPD dengan suplementasi Zeocin setelah diinkubasi selama 4 hari. Hal ini menunjukkan bahwa plasmid telah terintegrasi ke dalam genom $P$. pastoris

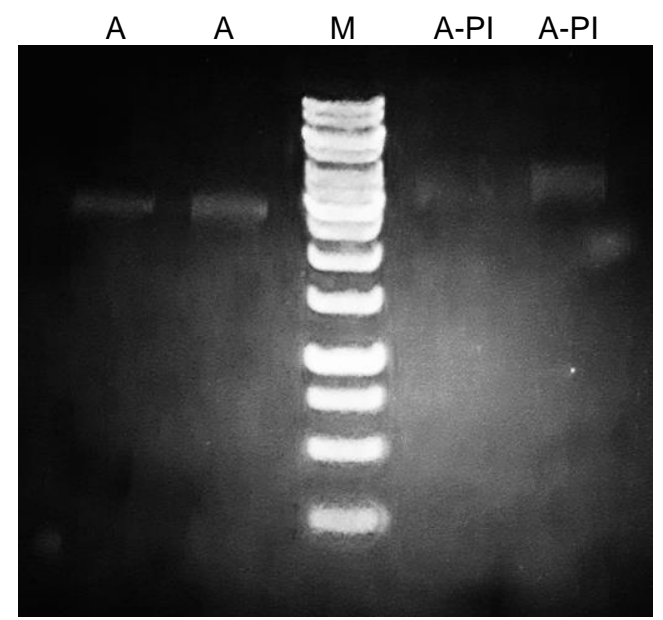

(a)

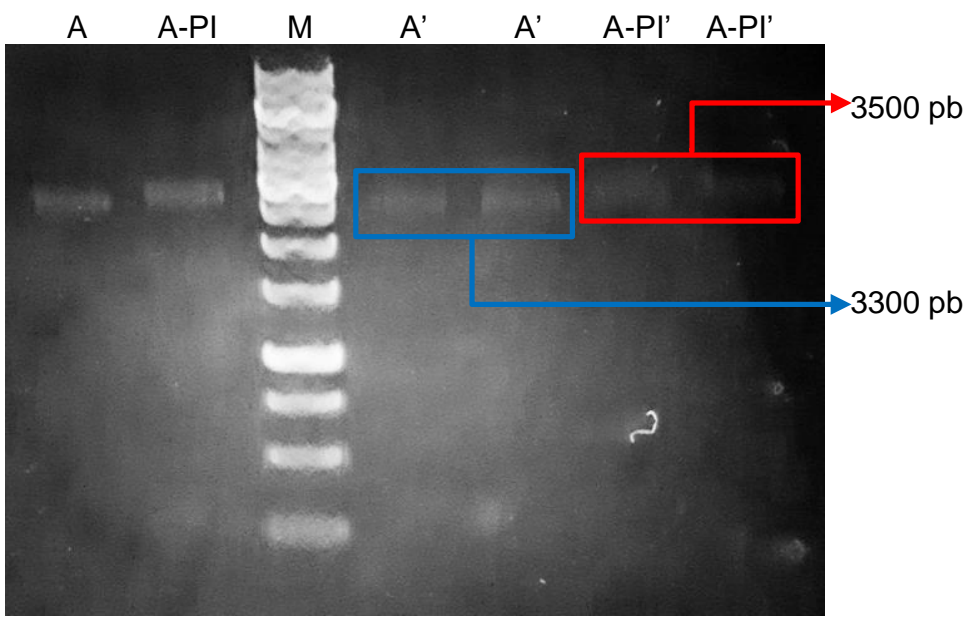

(b)

Gambar 2. Hasil: (a) isolasi plasmid dan (b) linearisasi plasmid. $A=p P I C Z A$ sebelum linearisasi, $A-P I=p P I C Z A-P I$ sebelum linearisasi, $M=$ Marka DNA $1 \mathrm{~kb}, \mathrm{~A}^{\prime}=$ pPICZA setelah linearisasi, $A-P I$ ' = pPICZA-PI setelah linearisasi 
sehingga sel dapat mengekspresikan protein resistensi Zeocin. Morfologi dari koloni $P$. pastoris hasil transformasi berbentuk bulat dengan warna putih krim. Permukaan koloni licin dan koloni memiliki konsistensi yang lunak sesuai dengan deskripsi ATCC $^{\circledR}$ $28485^{\mathrm{TM}}$. Berdasarkan kemampuan pertumbuhan $P$. pastoris rekombinan dalam media YPD dengan Zeocin, proses transformasi disimpulkan berhasil.

Sel kompeten juga ditumbuhkan dalam media YPD. Tujuan dari perlakuan ini adalah untuk melihat pengaruh persiapan sel kompeten terhadap viabilitas sel. Pada Gambar 4 ditunjukkan hasil inkubasi sel kompeten $P$. pastoris sebelum transformasi. Sel kompeten ditumbuhkan dalam media YPD dan diinkubasi pada suhu $28^{\circ} \mathrm{C}$ selama 2 hari.

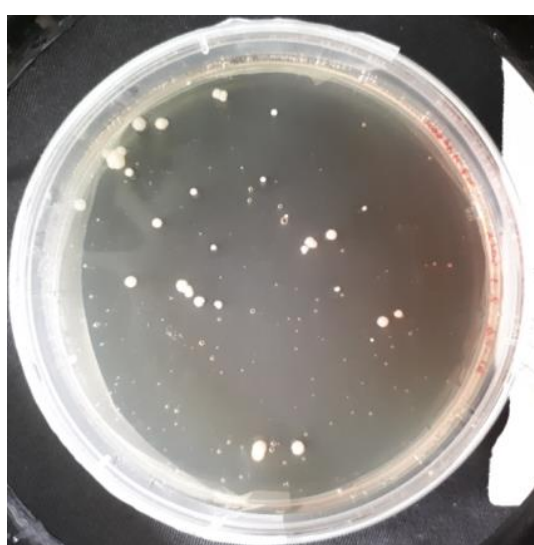

(a)

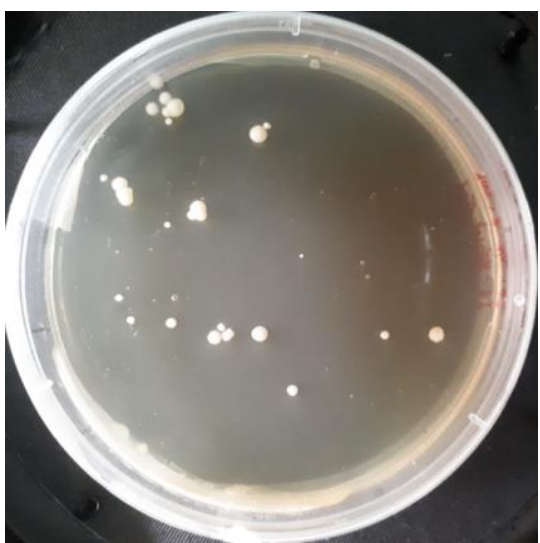

(d)

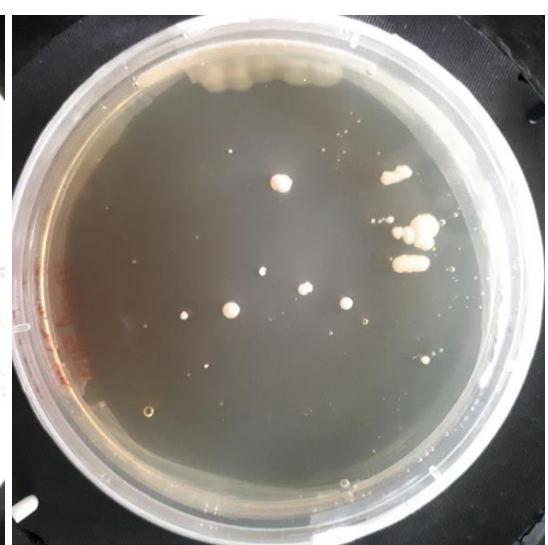

(b)

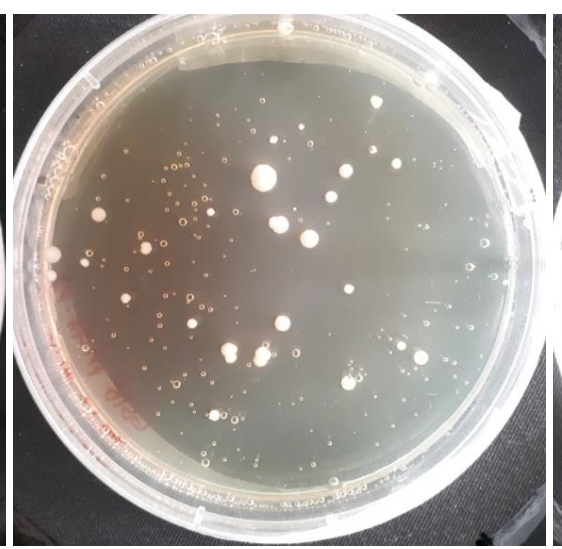

(e)

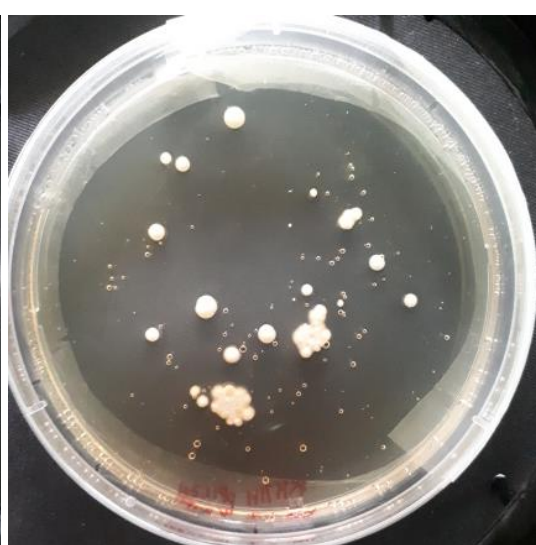

(c)

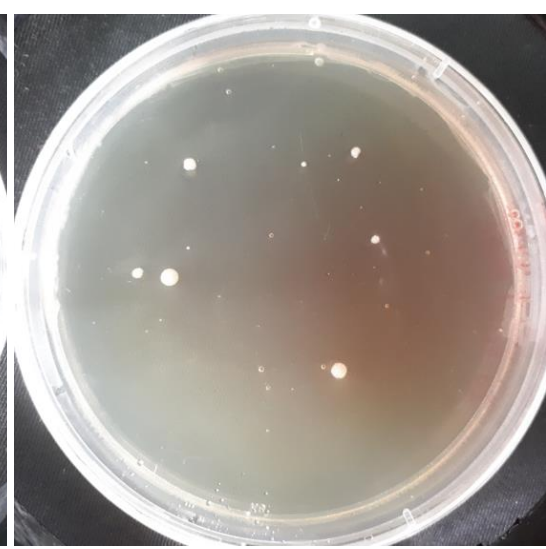

(f)

Gambar 3. Hasil transformasi Pichia pastoris: (a) X33A, (b) GS115A, (c) KM71HA, (d) X33-PI, (e) GS115-PI, dan (f) KM71H-PI

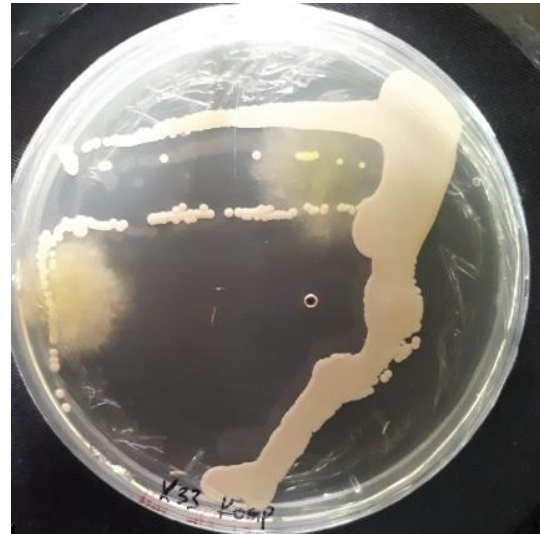

(a)

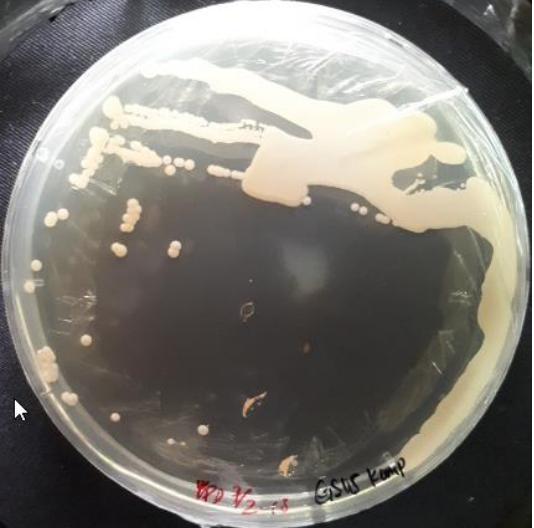

(b)

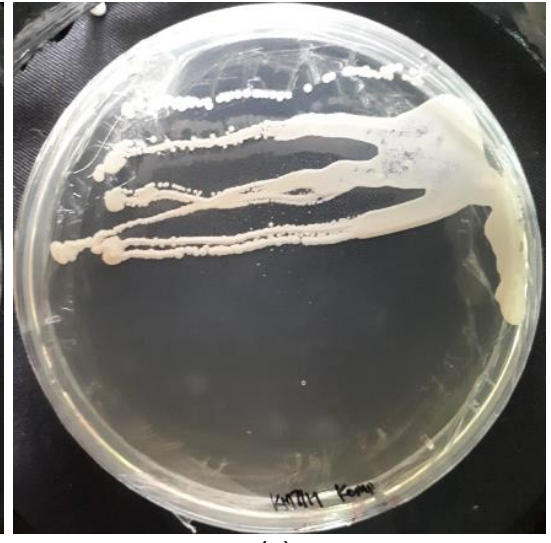

(c)

Gambar 4. Hasil regenerasi sel kompeten dalam media YPD: (a) X33, (b) GS115, dan (c) KM71H 
Hasil inkubasi menunjukkan sel kompeten dapat tumbuh dengan baik meskipun terdapat kontaminasi jamur pada media X33. Dari hasil ini dapat disimpulkan bahwa proses persiapan sel kompeten tidak merusak sel.

\section{Seleksi klon}

Hasil transformasi dari masing-masing $P$. pastoris rekombinan dengan gen sisipan memberikan beberapa koloni tunggal. Seleksi koloni dilakukan untuk memilih klon penghasil pita proinsulin terbaik dari masing-masing galur rekombinan. Berdasarkan perhitungan bobot molekul (BM) dengan menggunakan software Expassy, proinsulin hasil ekspresi $P$. pastoris rekombinan berukuran $6 \mathrm{kDa}$ dan terdiri dari 53 asam amino. Sehingga pita proinsulin akan berada di antara marka protein terbawah yang berukuran $10 \mathrm{kDa}$ dengan standar insulin dengan ukuran 5,8 kDa. Ekspresi proinsulin telah dilakukan pada suhu $30^{\circ} \mathrm{C}$ namun tidak terlihat pita proinsulin (data tidak ditampilkan). Oleh karena itu, suhu ekspresi diturunkan menjadi $25^{\circ} \mathrm{C}$. Penurunan suhu ini didasarkan dari hasil literatur beberapa jurnal penelitian. Beberapa hasil penelitian menunjukkan penurunan suhu ekspresi $P$. pastoris memberikan hasil yang lebih tinggi (Li et al, 2014; Maity et al, 2015; dan Prabhu et al, 2016). Beberapa penelitian lain juga menunjukkan bahwa proses ekspresi protein rekombinan lebih baik pada suhu rendah seperti pada suhu $23^{\circ} \mathrm{C}(\mathrm{Wu}$ et al. 2012). Pita proinsulin mulai terlihat pada suhu ekspresi ini (Gambar 5). Hal ini menunjukkan bahwa proses ekspresi proinsulin lebih baik dilakukan dalam suhu rendah.

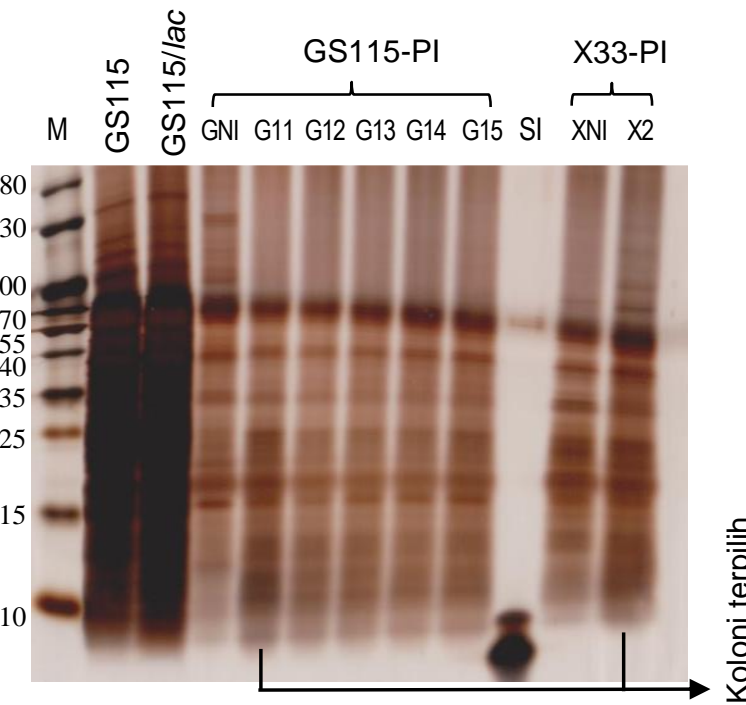

Pita proinsulin terlihat setelah dilakukan pewarnaan perak. Perbandingan ketebalan pita dilihat secara visual. Ketebalan pita tidak diukur dengan menggunakan perangkat lunak karena kerapatan antar pita sehingga antar pita tidak terpisah. Pita proinsulin paling tebal dari GS115-PI ditunjukkan oleh koloni nomor 11 yang selanjutnya disebut G11, untuk galur X33-PI ditunjukkan oleh koloni nomor 2 yang selanjutnya disebut $\mathrm{X} 2$, dan untuk galur $\mathrm{KM} 71 \mathrm{H}-\mathrm{PI}$ ditunjukkan oleh koloni nomor 4 yang selanjutnya disebut $\mathrm{K} 4$. Analisis seleksi koloni telah dilakukan sebanyak tiga kali dan memberi hasil yang konsisten sehingga membuktikan bahwa koloni terpilih merupakan penghasil pita proinsulin terbaik (Gambar 5).

\section{Konfirmasi hasil integrasi}

Proses konfirmasi integrasi gen sisipan ke dalam genom $P$. pastoris dilakukan dengan dua tahap yaitu isolasi genom $P$. pastoris rekombinan serta amplifikasi gen sisipan dengan PCR. Konsentrasi genom yang diperoleh kemudian diukur dengan menggunakan Nanodrop ${ }^{\mathrm{TM}}$. Rata-rata hasil isolasi genom mencapai $\pm 3000 \mathrm{ng} / \mu \mathrm{L}$. Hasil isolasi genom ini kemudian diencerkan sebanyak $50 \times$ agar dapat dipakai sebagai cetakan DNA. Konsentrasi hasil pengenceran genom berada pada rentang 100-700 ng/ $\mathrm{L}$. Kemurnian genom yang dilihat dari rasio 260/280 memberi angka di atas 2. Hal ini menunjukkan adanya kontaminasi RNA yang dapat dicegah dengan penambahan RNAse untuk isolasi genom selanjutnya (Ashram et al. 2016).

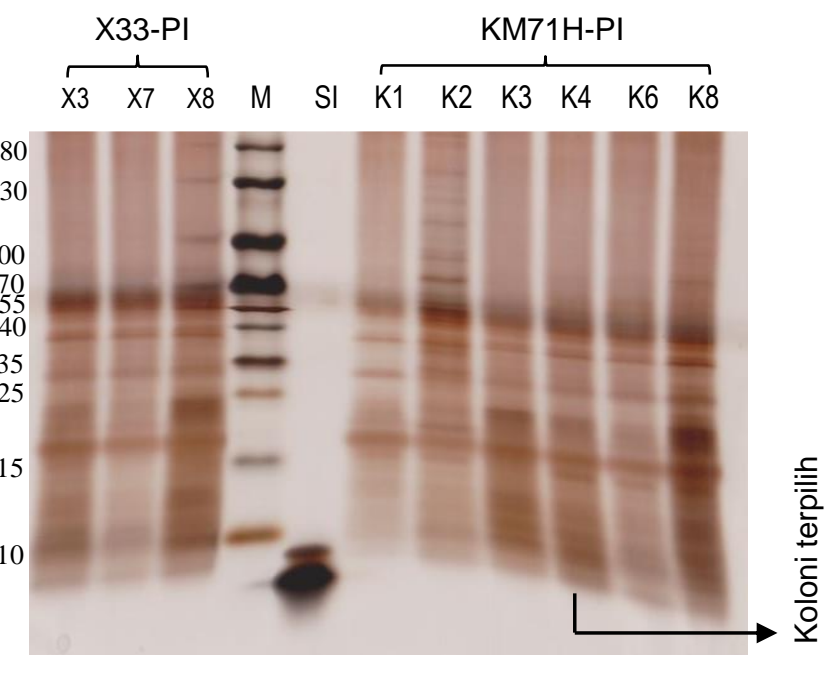

Gambar 5. Seleksi koloni dengan suhu ekspresi $25^{\circ} \mathrm{C}$. Panah hitam menandakan koloni yang dipilih 
$P$. pastoris rekombinan yang memiliki gen sisipan akan menghasilkan amplikon berukuran $504 \mathrm{pb}$ yang merupakan ukuran

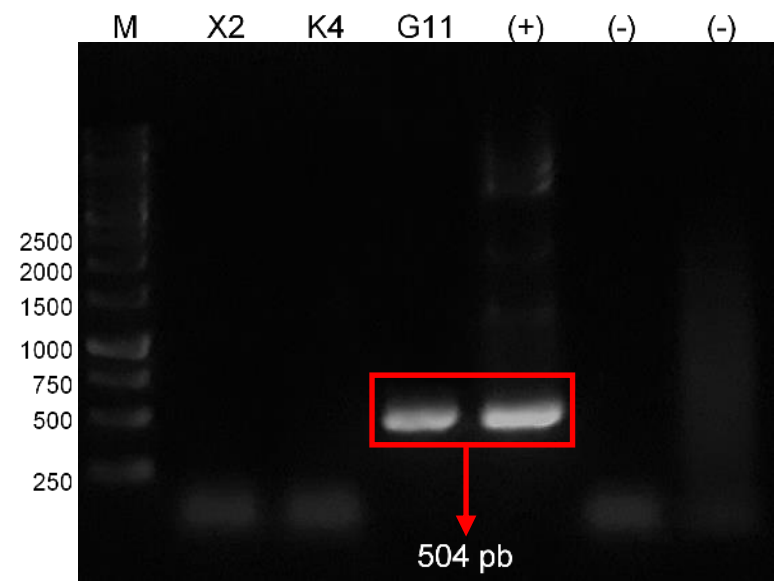

Gambar 6. Amplifikasi gen sisipan dari genom $P$. pastoris rekombinan. (+) merupakan kontrol positif, (-) merupakan kontrol negatif. Pita amplikon yang sesuai dihasilkan oleh koloni G11 gen AOX1 (325 pb) ditambah ukuran gen sisipan (179 pb). Berdasarkan hasil elektroforesis yang ditampilkan dalam Gambar 6, hanya GS115-G11 yang menghasilkan pita amplikon berukuran 504 pb dan sesuai dengan kontrol positif. Kontrol positif yang digunakan adalah plasmid pPICZA-PI hasil isolasi dari $E$. coli rekombinan. Sehingga, hasil ini mendukung hasil analisis seleksi galur yaitu GS115-G11 merupakan galur yang dapat menghasilkan proinsulin. Galur X33-X2 dan KM71H-K4 tidak memberikan pita amplikon yang diharapkan. Hal ini bisa juga dilihat dari konsentrasi cetakan genom dari masingmasing galur yang belum optimum. Menurut Lorenz (2012), jumlah cetakan yang dipakai dalam proses PCR berpengaruh terhadap hasil yang diberikan. Jumlah cetakan ini menunjukkan jumlah salinan cetakan DNA yang mengandung sekuen komplemen dari primer PCR. Selain itu, salah satu faktor lain

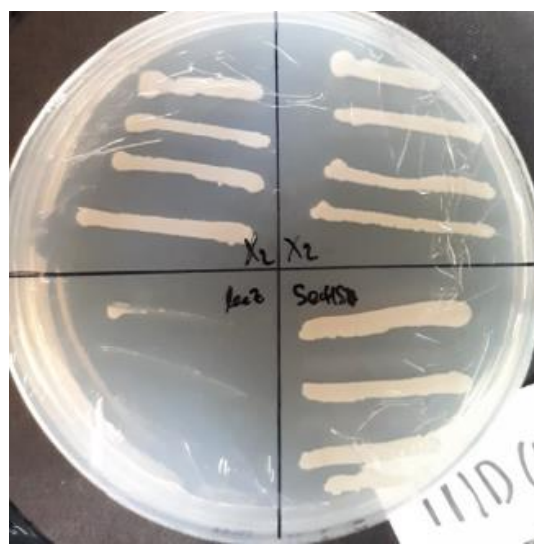

(a)

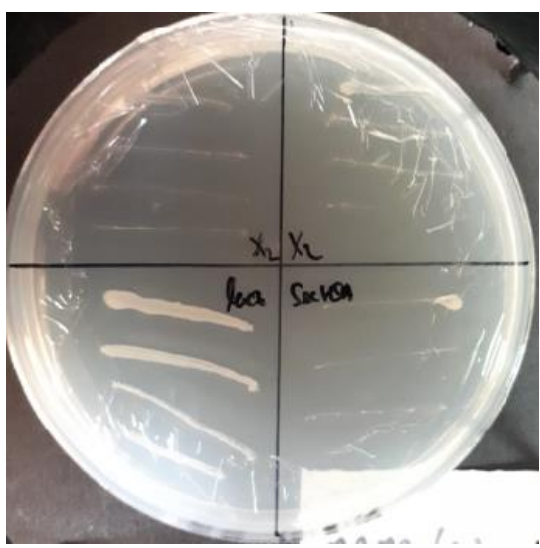

(d)

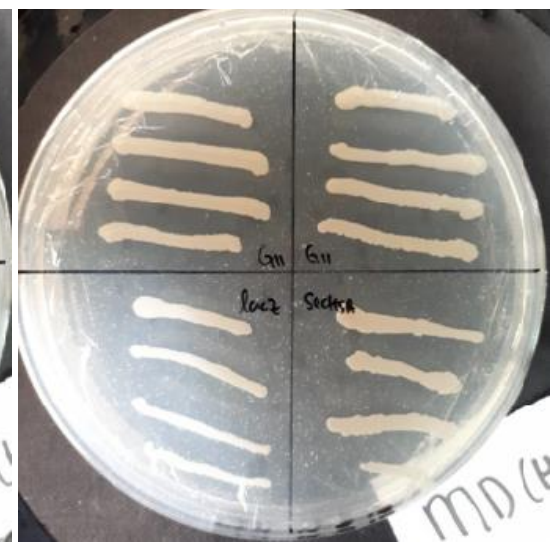

(b)

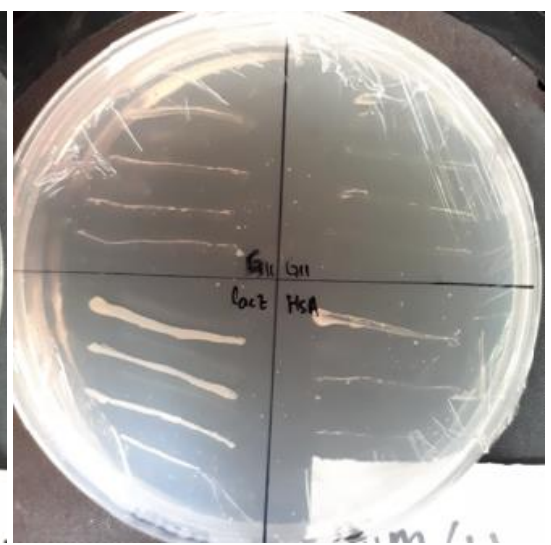

(e)

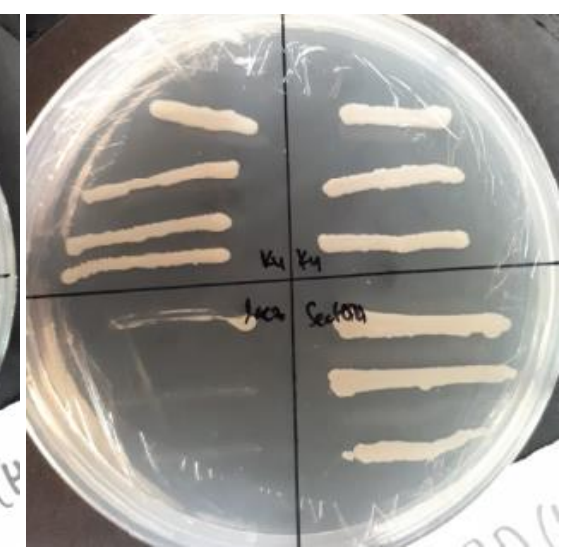

(c)

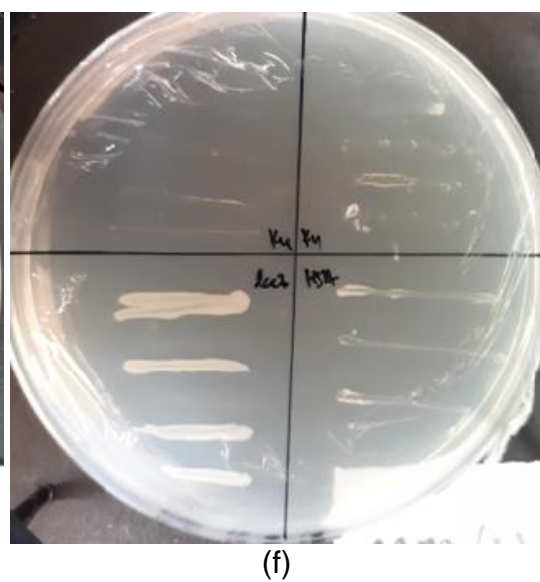

Gambar 7 Uji fenotipe tiga koloni $P$. pastoris terpilih: (a) X33-X2 pada MD, (b) GS115-G11 pada MDH, (c) KM71H-K4 pada MD, (d) X33-X2 pada MM, (e) GS115-G11 pada MMH, dan (e) KM71H-K4 pada MM. (Keterangan media: $\mathrm{MD}=$ Minimal Dextrose, $\mathrm{MM}=$ Minimal Methanol, $\mathrm{MDH}=$ Minimal Dextrose with histidine, dan MMH = Minimal Methanol with histidine. Setiap cawan dibagi empat sektor, dari sektor bagian atas kiri searah jarum jam: sampel $P$. pastoris terpilih (2 sektor), GS115 Sec HSA, dan GS115/pPICZA/lacz. Pertumbuhan koloni yang ditampilkan merupakan hasil pengamatan hari kedua) 
yang mungkin terjadi adalah proses annealing yang tidak terjadi pada sampel X33-X2 dan KM71H-K4 sehingga tidak terjadi amplifikasi gen proinsulin. Suhu annealing pada umumnya berada pada rentang 5258드. (Lorenz 2012). Sehingga pada penelitian berikutnya perlu dilakukan optimasi konsentrasi cetakan dan suhu annealing untuk galur X33-X2 dan $\mathrm{KM} 71 \mathrm{H}-\mathrm{K} 4$.

Fenotipe dari $P$. pastoris rekombinan juga dapat dianalisis melalui hasil elektroforesis di atas. $P$. pastoris dengan fenotipe $\mathrm{Mut}^{+}$akan menghasilkan pita amplikon berukuran 2,2 kb. Namun hasil elektroforesis diatas tidak menunjukkan adanya pita berukuran 2,2 kb dari sampel sehingga terbukti bahwa fenotipe $P$. pastoris rekombinan terpilih merupakan Mut ${ }^{S}$.

\section{Uji fenotipe $\boldsymbol{P}$. pastoris rekombinan}

Uji fenotipe dilakukan untuk mengetahui fenotipe dari $P$. pastoris setelah proses transformasi. Koloni uji disimpulkan memiliki fenotipe Mut $^{+}$jika dapat tumbuh normal di kedua media minimal, sedangkan fenotipe Mut $^{\mathrm{S}}$ jika mengalami pertumbuhan normal di media minimal dekstrosa namun mengalami pertumbuhan yang lambat atau tidak tumbuh sama sekali di media minimal metanol.

Hasil uji fenotipe ditampilkan dalam Gambar 7. Dalam uji fenotipe ini, terdapat dua kontrol yang ditumbuhkan dalam masing-masing media minimal yaitu GS115/pPICZ/lacz dan GS115 Albumin. GS115/pPICZ/lacz merupakan kontrol

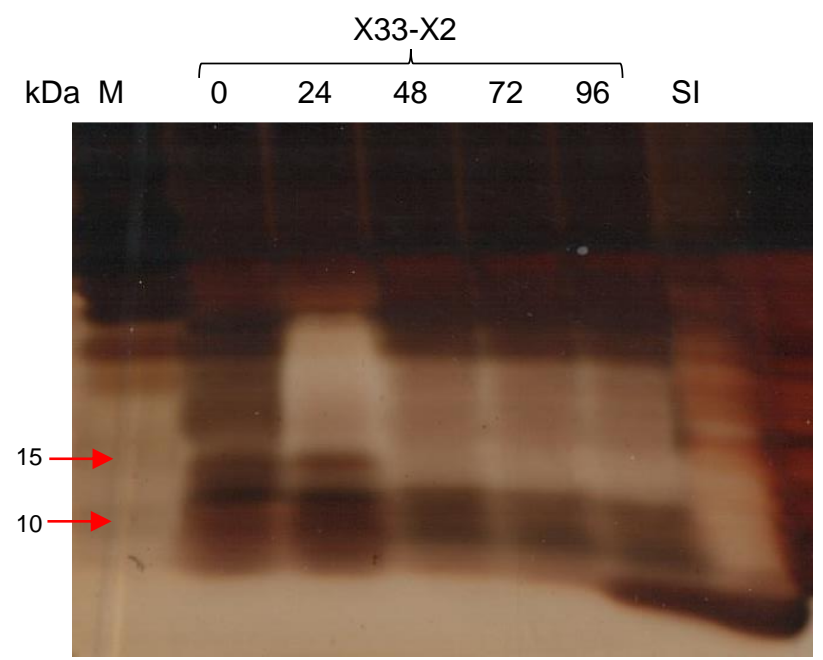

untuk Mut $^{+}$sedangkan GS115/Albumin merupakan kontrol untuk Muts. GS115/pPICZ/lacz mengalami pertumbuhan yang normal pada kedua jenis media sedangkan GS115/Albumin mengalami pertumbuhan yang lambat pada media yang mengandung metanol. Hal ini membuktikan bahwa kedua jenis kontrol fenotipe tersebut sudah sesuai dengan teori. Hal ini juga sesuai dengan hasil penelitian dari Alias et al. (2011).

Koloni X33-X2 yang ditumbuhkan mengalami pertumbuhan normal pada media MD, namun mengalami perlambatan pertumbuhan pada media MM. Perbedaan kemampuan pertumbuhan ini juga diamati dari koloni GS115-G11, begitu juga dari koloni $\mathrm{KM} 71 \mathrm{H}-\mathrm{K} 4$. Berdasarkan hasil analisis ini, disimpulkan bahwa fenotipe dari ketiga koloni uji merupakan Mut ${ }^{\mathrm{S}}$.

$P$. pastoris dengan fenotipe Mut $^{\mathrm{s}}$ memiliki keuntungan dibanding $P$. pastoris fenotipe Mut $^{+}$. Galur Mut $^{\mathrm{S}}$ tidak memerlukan metanol dan oksigen dengan jumlah sebanyak yang dibutuhkan galur Mut ${ }^{+}$dalam proses peningkatan produksi (misalnya skala industri) (Cereghino dan Cregg 2000). Meskipun begitu, galur Mut ${ }^{\mathrm{S}}$ akan membutuhkan waktu induksi yang lebih panjang karena penggunaan metanol yang lebih lambat. Berdasarkan penelitian Orman et al. (2009) dan Krainer et al. (2012), P. pastoris dengan fenotipe Mut $^{\mathrm{S}}$ memiliki tingkat produksi dan efisiensi yang lebih tinggi dalam ekspresi protein rekombinan.

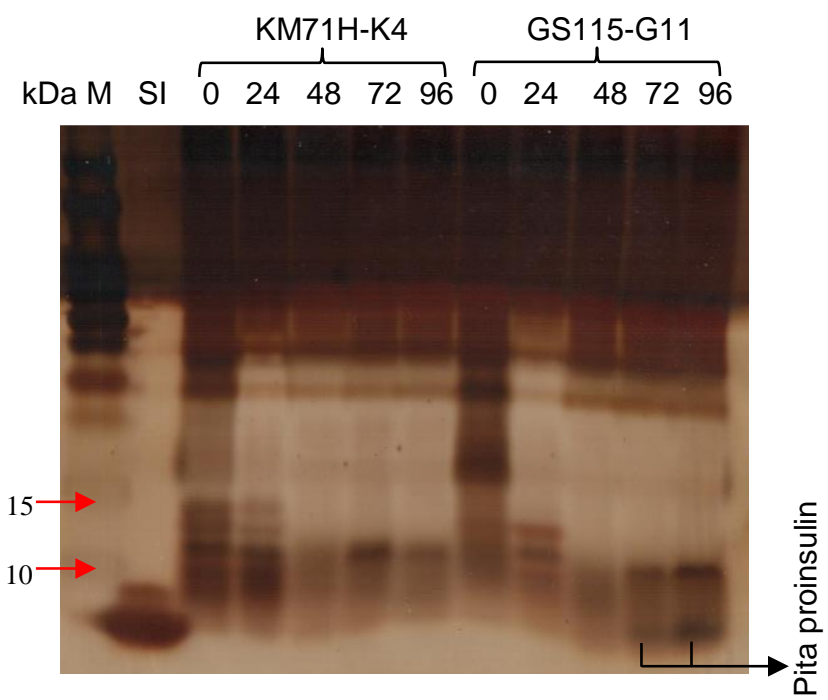

Gambar 8. Hasil seleksi galur. $\mathrm{M}=$ marka protein, $\mathrm{SI}=$ standar insulin. Kultur disampling pada jam ke- 0, 24, 48, 72, dan 96. Pita proinsulin yang terekspresikan oleh GS115-G11 


\section{Seleksi galur}

Seleksi galur dilakukan dengan tujuan untuk memilih galur yang dapat mengekspresikan proinsulin terbaik. Hasil seleksi galur ditampilkan dalam Gambar 8. Berdasarkan Gambar 8, pita proinsulin tidak terlihat jelas dari galur $\mathrm{X} 33-\mathrm{X} 2$ dan $\mathrm{KM} 71 \mathrm{H}$ K4. Meskipun pada lajur X2 induksi jam ke-96 memberikan pita yang tebal namun terlihat bahwa pita tersebut berdekatan dengan standar insulin. Hal ini menyebabkan pita tersebut tidak dapat disimpulkan sebagai pita proinsulin. Pada KM71H-K4, terdapat pita yang memiliki posisi sama dengan pita proinsulin namun pita tersebut samar-samar. Hal ini mungkin dikarenakan jumlah proinsulin yang sedikit. Pita proinsulin terlihat

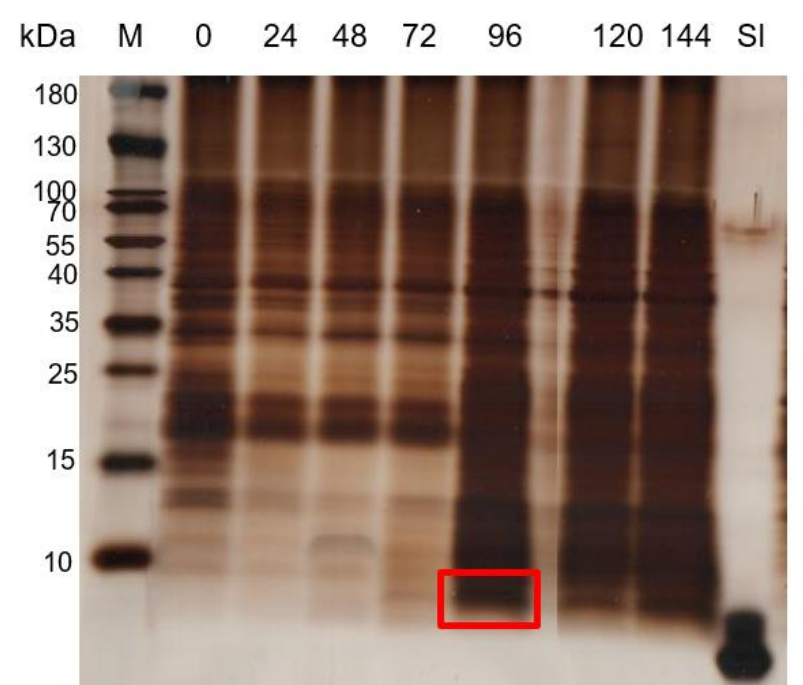

(a)
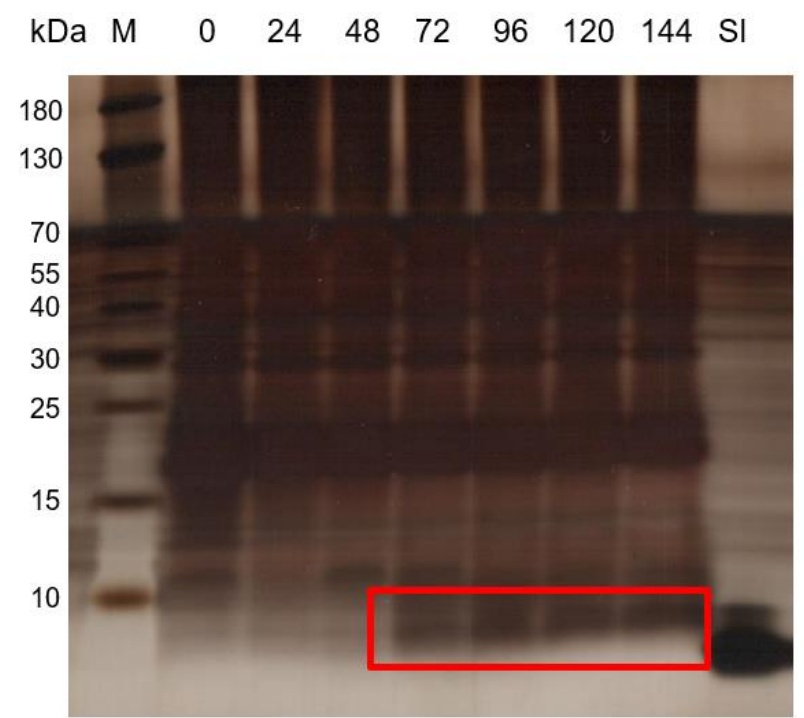

(c) jelas dari galur GS115-G11 dan semakin tebal dari jam 72 ke jam 96. Berdasarkan hasil perbandingan ini, galur GS115-G11 merupakan galur yang dipilih untuk analisis pengaruh variasi metanol terhadap ekspresi proinsulin.

\section{Optimasi ekspresi proinsulin}

Proses optimasi ekspresi proinsulin dilakukan dengan melakukan variasi konsentrasi akhir metanol sebagai penginduksi dalam media fermentasi. Tujuan dari perlakuan ini adalah untuk mengkaji pengaruh variasi konsentrasi metanol yang diberikan terhadap ekspresi proinsulin. Hasil variasi konsentrasi akhir metanol ditampilkan dalam Gambar 9.

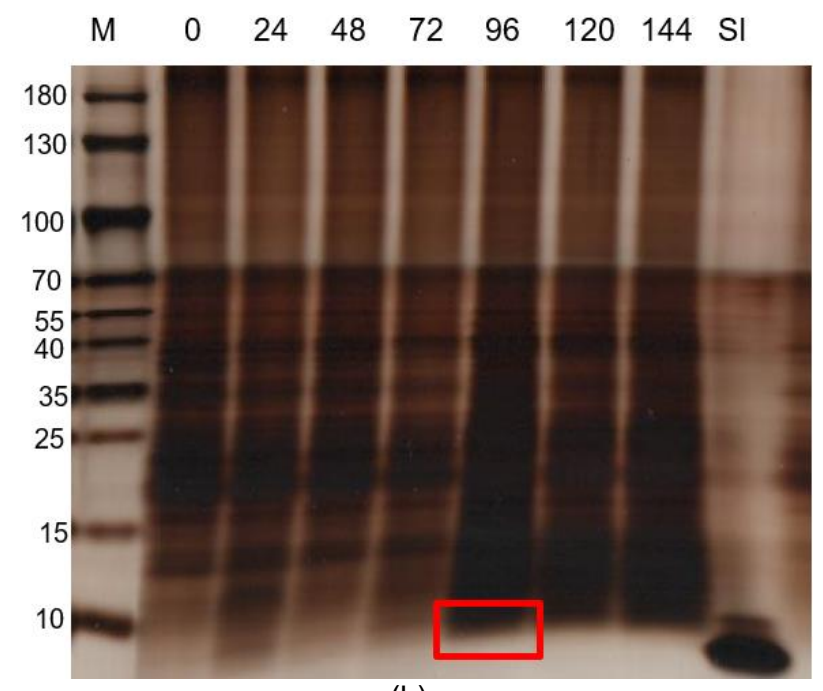

(b)
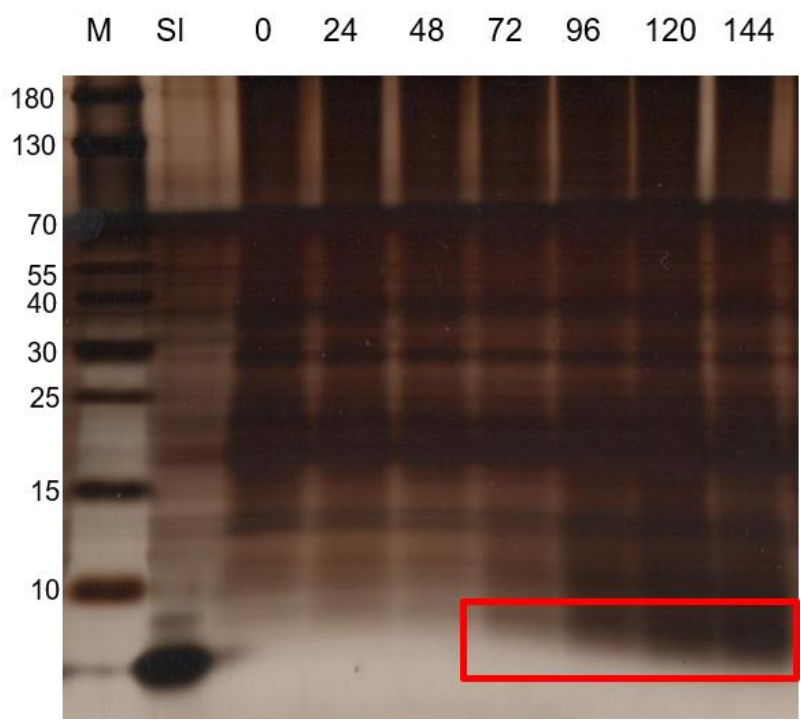

(d)

Gambar 9. Variasi konsentrasi akhir metanol terhadap ekspresi proinsulin (kotak merah). Keterangan konsentrasi akhir metanol: $\mathrm{kDa}=\mathrm{BM}$ marka protein, $\mathrm{M}=$ marka protein, $\mathrm{SI}=$ standar insulin, (a) 0,5\%, (b) 1\%, (c) 1,5\%, dan (d) $2 \%$. Kultur disampling pada jam ke-0, 24, 48, 72, 96, 120, dan 144 
Pita proinsulin berhasil diekspresi dari masing-masing variasi konsentrasi metanol dengan kecenderungan yang berbeda. Hasil variasi metanol dengan konsentrasi akhir sebesar $0,5 \%$ dan $1 \%$ memberikan pita proinsulin yang terlihat jelas setelah 72 jam induksi dan semakin tebal sampai 144 jam induksi. Pita yang dihasilkan dari induksi metanol $1 \%$ lebih tebal dibanding pita hasil induksi metanol $0,5 \%$. Hal ini menunjukkan peningkatan konsentrasi metanol sebesar $1 \%$ meningkatkan ekspresi proinsulin. Meskipun demikian, penggunaan metanol dengan konsentrasi akhir metanol sebesar 0,5\% sudah dapat mengekspresikan proinsulin.

Pita proinsulin dari hasil induksi metanol sebesar $1,5 \%$ dan $2 \%$ mulai terlihat dari setelah induksi 96 jam. Pita proinsulin paling tebal hasil induksi metanol 1,5\% terlihat pada jam 96. Pita proinsulin menipis seiring bertambahnya waktu induksi meskipun tidak terlalu jelas secara visual. Ketebalan pita proinsulin secara visual dari hasil induksi metanol sebesar 2\% tidak meningkat jauh dibanding pita proinsulin hasil induksi metanol $1,5 \%$. Secara visual, ketebalan pita proinsulin pada jam ke-96 dari hasil induksi metanol $1,5 \%$ sama dengan pita proinsulin jam ke-96 dari induksi metanol dengan konsentrasi akhir $2 \%$. Berdasarkan perbandingan di atas dan dilihat dari kecepatan pembentukan pita proinsulin, induksi metanol $0,5 \%$ merupakan konsentrasi yang paling baik untuk mengekspresikan proinsulin.

\section{KESIMPULAN}

Berdasarkan hasil penelitian yang diperoleh disimpulkan bahwa proses transformasi $P$. pastoris berhasil sehingga $P$. pastoris rekombinan dapat tumbuh pada media dengan suplementasi Zeocin. Fenotipe transforman semua galur merupakan fenotipe Mut $^{S}$. Berdasarkan hasil analisis SDS-PAGE, GS115 merupakan galur yang dapat mengekspresikan proinsulin secara intraseluler. Hasil induksi metanol 0,5\% dan lama induksi 72 jam memberikan pita proinsulin paling tebal dan cepat dibandingkan dengan variasi lain.

\section{DAFTAR PUSTAKA}

Ahmad M, Hirz M, Pichler $\mathrm{H}$, Schwab $\mathrm{H}$ (2014) Protein expression in Pichia pastoris: Recent achievements and perspectives for heterologous protein production. Appl Microbiol Biotechnol 98:5301-5317. doi: 10.1007/s00253014-5732-5

Alias NI, Mahadi NM, Murad AMA, Abu-Bakar FD, Rabu A, Illias RM (2011) Expression optimisation of recombinant $\alpha$-L-arabinofuranosidase from Aspergillus niger ATCC 120120 in Pichia pastoris and its biochemical characterisation. Afr $\mathrm{J}$ Biotechnol 10:6700-6710. doi: 10.5897/AJB10.873

Baeshen MN, Bouback TA, Alzubaidi MA, Bora RS, Alotaibi MA, Alabbas OT, Alshahrani SM, Aljohani AA, Munshi RA, Hejin AA, Ahmed MM, Redwan EM, Ramadan HA, Saini KS, Baeshen NA (2016) Expression and purification of Cpeptide contaning insulin using Pichia pastoris expression system. BioMed Res Int 2016:1-7. doi: 10.1155/2016/3423685

Baeshen NA, Baeshen MN, Sheikh A, Bora RS, Ahed MM, Ramadan HA, Saini KS, Redwan EM (2014) Cell factories for insulin production. Microb Cell Fact 13:141-150. doi: 10.1186/s12934-0140141-0

Cereghino JL, Cregg JM (2000). Heterologous protein expression in the methylotrophic yeast Pichia pastoris. FEMS Microbiol Rev 24:45-66. doi: 10.1111/j.1574-6976.2000.tb00532.x

Chevallet M, Luche S, Rabilloud T (2006) Silver staining of proteins in polyacrylamide gels. Nat Protoc 1:1852-1858. doi: 10.1038/nprot.2006.288

El-Ashram S, Al Nasr I, Suo X (2016) Nucleic acid protocols: Extraction and optimization. Biotechnol Rep (Amst) 12:33-39. doi: 10.1016/j.btre.2016.10.001

Gurramkonda C, Polez S, Skoko N, Adnan A, Gäbel T, Chugh D, Swaminathan S, Khanna N, Tisminetzky S, Rinas U (2010). Application of simple fed-batch technique to high-level secretory production of insulin precursor using Pichia pastoris with subsequent purification and conversion to human insulin. Microb Cell Fact 9:31. doi : 10.1186/1475-2859-9-31

Harju S, Fedosyuk H, Peterson KR (2004) 
Rapid isolation of yeast genomic DNA: Bust n' Grab. BMC Biotechnol 4:8. doi: 10.1186/1472-6750-4-8

IDF (2015) IDF Diabetes atlas. Seventh Edition. International Diabetes Federation, Brussels Belgium

Krainer FW, Dietzsch C, Hajek T, Herwig C, Spadiut O, Glieder A (2012) Recombinant protein expression in Pichia pastoris strains with an engineered methanol utilization pathway. Microb Cell Fact 11:22. doi: 10.1186/1475-2859-11-22

Li YY, Zhong KX, Hu AH, Liu DN, Chen LZ, Xu SD (2014) High-level expression and characterization of a thermostable xylanase mutant from Trichoderma reesei in Pichia pastoris. Protein Expr Purif 108:90-96. doi: 10.1016/j.pep.2014.11.014

Looser V, Brühlmann BB, Bumbak F, Stenger C, Costa M, Camattari A, Fotiadis D, Kovar K (2015) Cultivation strategies to enhance productivity of Pichia pastoris: A review. Biotechnol Adv 33:11771193.

doi:

10.1016/j.biotechadv.2015.05.008

Lorenz TC (2012) Polymerase Chain Reaction: Basic protocol plus troubleshooting and optimization strategies. J Vis Exp 63(e3938). doi: $10.3791 / 3998$

Maity N, Thawani A, Sharma A, Gautam A, Mishra S, Sahai V (2015) Expression and control of codon-optimized granulocyte colony-stimulating factor in Pichia pastoris. Appl Blochem Biotechnol 178:159-172. doi: 10.1007/s12010-015-1865-y

Orman MA, Calik P, Ozdamar TH (2009) The influence of carbon sources on recombinant-human growth-hormone production by Pichia pastoris is dependent on phenotype: A comparison of $\mathrm{Mut}^{\mathrm{s}}$ and $\mathrm{Mut}^{+}$strains. Biotechnol Appl Biochem 52:245-255. doi: 10.1042/BA20080057

Polez S, Origi D, Zahariev S, Guarnaccia C, Tisminetzky SG, Skoko N, Baralle M (2016) A simplified and efficient process for insulin production in Pichia pastoris. PLoS One 11:e0167207. doi: 10.1371/journal.pone.0167207

Prabhu AA, Veeranki VD, Dsilva SJ (2016) Improving the production of human interferon gamma (hIFN- $\gamma$ ) in Pichia pastoris cell factory: An approach of cell level. Process Biochem 51:709-718. doi: 10.1016/j.procbio.2016.02.007

Pronobis MI, Deuitch N, Peifer M (2016) The Miraprep: A protocol that uses a miniprep kit and provides maxiprep yields. PLoS One 11:e0160509. doi: 10.1371/journal.pone.0160509

Quianzon CC, Cheikh I (2012) History of insulin. J Community Hosp Intern Med Perspect 2:1-3. doi: 10.3402/jchimp.v2i2.18701

Safder I, Khan S, Islam I, Ali MK, Bibi Z, Waqas $M$ (2018) Pichia pastoris expression system: A potential candidate to express protein in industrial and biopharmaceutical domains. Biomed Lett 4:1-14

Samalla P (2015) Transformation of the X-33 strain of Pichia pastoris and the small

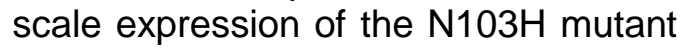
hen egg white lysozyme gene. Thesis, Youngtown State University

Sambrook JF, Russel DW (2001) Molecular cloning: A laboratory manual. Cold Spring Harbor Laboratory Press, New York

Schagger H (2006) Tricine-SDS-PAGE. Nature Protocols 1:16-22. doi: 10.1038/nprot.2006.4

Shen W, Kong C, Xue Y, Liu Y, Cai M, Zhang Y, Jiang T, Zhou X, Zhou M (2016) Kinase screening in Pichia pastoris identified promising targets involved in cell growth and alcohol oxidase 1 Promoter (PAOX1) regulation. PLoS One 11:e0167766. doi: 10.1371/journal.pone.0167766.

Strumberger L, Chappell T, Geier M, Krainer F, Day KJ, Vide U, Trstenjak S, Schiefer A, Richardson T, Soriaga L, Darnhofer $B$, Birner-Gruenberger R, Glick BS, Tolstorukov I, Cregg J, Madden K, Glieder A (2016) Refined Pichia pastoris reference genome sequence. J Biotechnol 235:121-131. doi: 10.1016/j.jbiotec.2016.04.023

Vanz AL, Nimtz M, Rinas U (2014) Decrease of UPR- and ERAD-related proteins in Pichia pastoris during methanolinduced secretory insulin precursor production in controlled fed-batch cultures. Microb Cell Fact 13:23. doi: 10.1186/1475-2859-13-23 
von der Haar T (2007) Optimized protein extraction for quantitative proteomics of yeasts. PLoS One 2(10): e1078. doi: 10.1371/journal.pone.0001078

WHO (2016) Global Report on Diabetes. WHO Press, France

Wu JM, Wang SY, Fu WC (2012) Lower temperature cultures enlarge the effects of vitreoscilla hemoglobin expression on recombinant Pichia pastoris. Int J Mol Sci 13:13212-13226. doi: 10.3390/ijms131013212

Yin H, Liu Z, Zhang A, Zhang T, Luo J, Shen J, Chen L, Zhou B, Fu X, Fu C, Zhang $Z$ (2012) Intracellular expression and purification of the Canstatin-N protein in Pichia pastoris. Gene 504:122-126. doi: 10.1016/j.gene.2012.04.073 